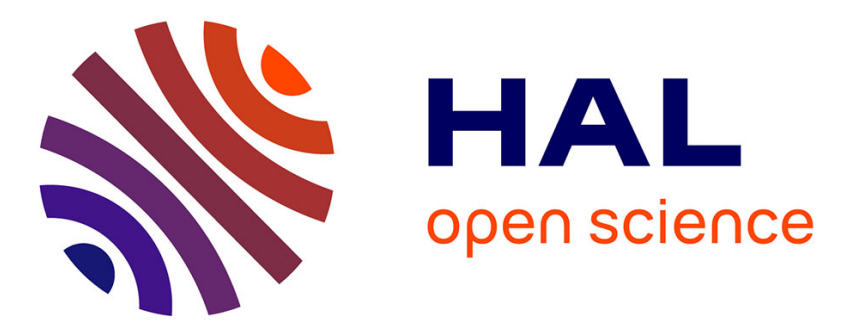

\title{
Dithiolene complexes as metallo-ligands: a crown-ether approach
}

Alessia Famengo, Dalice Pinero, Olivier Jeannin, Thierry Guizouarn, Lidia Piekara-Sady, Marc Fourmigué

\section{- To cite this version:}

Alessia Famengo, Dalice Pinero, Olivier Jeannin, Thierry Guizouarn, Lidia Piekara-Sady, et al.. Dithiolene complexes as metallo-ligands: a crown-ether approach. New Journal of Chemistry, 2012, 36, pp.638-643. 10.1039/c1nj20870e . hal-00673825

\section{HAL Id: hal-00673825 \\ https://hal.science/hal-00673825}

Submitted on 15 Jul 2013

HAL is a multi-disciplinary open access archive for the deposit and dissemination of scientific research documents, whether they are published or not. The documents may come from teaching and research institutions in France or abroad, or from public or private research centers.
L'archive ouverte pluridisciplinaire HAL, est destinée au dépôt et à la diffusion de documents scientifiques de niveau recherche, publiés ou non, émanant des établissements d'enseignement et de recherche français ou étrangers, des laboratoires publics ou privés. 


\title{
Dithiolene complexes as metallo-ligands: a crown-ether approach $\dagger$
}

\author{
Alessia Famengo, ${ }^{a b}$ Dalice Pinero, ${ }^{a}$ Olivier Jeannin, ${ }^{* a}$ Thierry Guizouarn, ${ }^{a}$ \\ Lidia Piekara-Sady ${ }^{c}$ and Marc Fourmigué ${ }^{* a}$
}

\author{
Received (in Victoria, Australia) 10th October 2011, Accepted 17th November 2011 \\ DOI: $10.1039 / \mathrm{c} 1 \mathrm{nj} 20870 \mathrm{e}$
}

A nickel dithiolene complex substituted with crown ether cyclic moieties incorporating four $\mathrm{O}$ atoms, abbreviated as $\left[\mathrm{Ni}\left(\mathrm{S}_{2} \mathrm{O}_{4}\right)_{2}\right]^{1-, 0}$, is isolated in its radical anionic (as $\mathrm{Na}^{+}$salt) and neutral

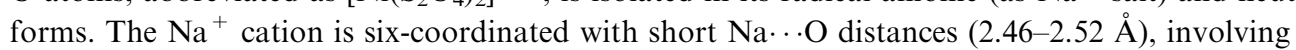
two crown ether moieties of two different complexes. The oxidized neutral complex $\left[\mathrm{Ni}\left(\mathrm{S}_{2} \mathrm{O}_{4}\right)_{2}\right]^{0}$ was also isolated and structurally characterized. In the absence of alkaline cations during the synthesis, a mixed salt associating $\left[\mathrm{Ni}\left(\mathrm{S}_{2} \mathrm{O}_{4}\right)_{2}\right]^{1-}$ with $\mathrm{Ni}^{2+}$ was isolated, and formulated as $\left(\mathrm{Ni}, \mathrm{H}_{2} \mathrm{O}\right)\left[\mathrm{Ni}\left(\mathrm{S}_{2} \mathrm{O}_{4}\right)_{2}\right]_{2}$, with the $\mathrm{Ni}^{2+}$ cation weakly bonded to two crown ether moieties. The salt exhibits an unprecedented solid state association with extremely short $\mathrm{S}$. S S intermolecular contacts $[3.332(2) \AA]$, leading to a pairing of the radical $\left[\mathrm{Ni}\left(\mathrm{S}_{2} \mathrm{O}_{4}\right)_{2}\right]^{-}$into antiferromagnetic uniform spin chains.

\section{Introduction}

Paramagnetic metal dithiolene complexes ${ }^{1}$ are currently extensively investigated for their conducting and magnetic properties, ${ }^{2}$ with the most common magnetic species found among the $\left.S=\frac{1}{2} \mathrm{~d}^{9}[\mathrm{Cu} \text { (dithiolene })_{2}\right]^{2-}$ copper complexes, the formally $\mathrm{d}^{7}, S=\frac{1}{2}\left[\mathrm{M}(\text { dithiolene })_{2}\right]^{1-}$ nickel, palladium or platinum anionic complexes, ${ }^{2,3}$ and the $\left[\mathrm{Au}(\text { dithiolene })_{2}\right]^{\bullet}$ gold neutral complexes. ${ }^{4,5}$ The electronic properties of these "simple" salts are essentially controlled by the overlapping interactions between radical species. Weak interactions favour the observation of localized magnetic states (dimers, spin chains, spin ladders, ...) while stronger interactions might allow the formation of conduction bands ${ }^{2 a}$ and associated metallic behavior of the conductivity.

Paramagnetic dithiolene complexes can also be considered as elementary building blocks for more elaborated architectures where they would play the role of a metallo-ligand toward other metallic centers, ${ }^{6,7}$ provided that they bear substituents adapted for further outer coordination, essentially through the lone pairs of nitrogen (nitrile and pyridine functions) or oxygen (ether and carbonyl functions) atoms. For example, derivatives of nitrile containing complexes ${ }^{3,8}$ such as $\left[\mathrm{M}(\mathrm{mnt})_{2}\right]^{2-, 1-}$ or $\left[\mathrm{M}(\mathrm{tfadt})_{2}\right]^{2-, 1-}$ were found to successfully coordinate other metallic centers through nitrogen atoms,

\footnotetext{
${ }^{a}$ Sciences Chimiques de Rennes, Université Rennes $1 \&$

CNRS UMR 6226, Campus de Beaulieu, 35042 Rennes, France.

E-mail: olivier.jeannin@univ-rennes1.fr,

marc.fourmigue@univ-rennes1.fr

${ }^{b}$ Dipartimento di Scienze Chimiche, Università degli Studi di Padova, via Marzolo 1, 35131 Padova, Italy

${ }^{c}$ Institute of Molecular Physics, Polish Academy of Science,

M. Smoluchowskiego 17, 60-179 Poznań, Poland

$\dagger$ CCDC reference numbers 848302-848305. For crystallographic data

in CIF or other electronic format see DOI: $10.1039 / \mathrm{clnj} 20870 \mathrm{e}$
}

such as the $S=2 \mathrm{Mn}^{\mathrm{III}}$ porphyrin, $[\mathrm{Mn}(\mathrm{TPP})]^{+},{ }^{9}$ the $S=1$ $[\mathrm{Ni}(\text { cyclam })]^{2+}$ complex $^{10}$ and polymetallic complexes such as $\left[\mathrm{Mn}_{4}(\mathrm{hmp})_{6}\left(\mathrm{CH}_{3} \mathrm{CN}\right)_{2}\right]^{4+}$ (hmp: 2-hydroxymethylpyridinate). ${ }^{11,12}$ Other examples of nitrogen coordination can be also found in fused pyrazine ${ }^{13}$ or in 4-pyridyl derivatives. ${ }^{14}$ Complexes with oxygen-based coordinating functions are essentially limited to the chelating dithiooxalate (dto ${ }^{6}$ and dithiosquarate (dts) ligands. Because of the strong electron-withdrawing nature of the carbonyl groups, both ligands only stabilize the most reduced dianionic forms of the dithiolene complexes, for example the diamagnetic $\left[\mathrm{Ni}(\mathrm{dto})_{2}\right]^{2-}$ or the paramagnetic $\mathrm{d}^{9} S=\frac{1}{2}\left[\mathrm{Cu}(\mathrm{dto})_{2}\right]^{2-}$. The latter was indeed engaged in bimetallic polymeric chains with ferrimagnetic interactions upon $\mathrm{Mn}^{\mathrm{II}}$ coordination. ${ }^{15}$ Other examples involved the tris(dithiolene) complexes ${ }^{16}$ such as $[\mathrm{Cr}(\mathrm{dto})]^{3-}$ or the polymeric $\mathrm{N}\left(n-\mathrm{C}_{3} \mathrm{H}_{7}\right)_{4}\left[\mathrm{Co}^{\mathrm{II}} \mathrm{Fe}^{\mathrm{III}}(\mathrm{dto})_{3}\right] .{ }^{17}$

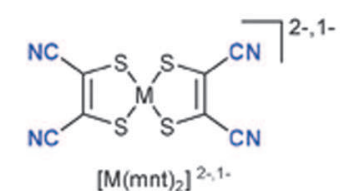

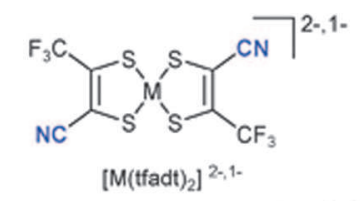

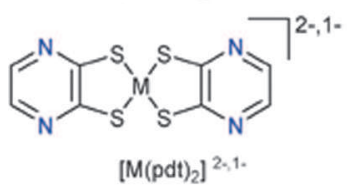

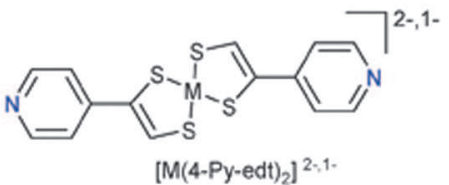

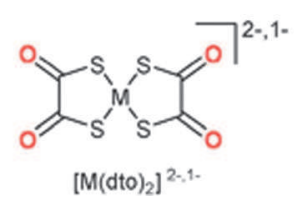

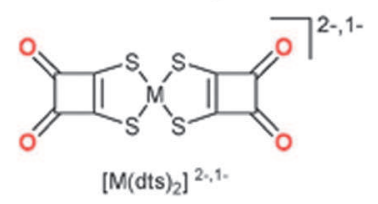


Looking for alternative substitution patterns which would work with the monoanionic, formally $\mathrm{d}^{7}, S=\frac{1}{2}$ $\left[\mathrm{Ni}(\text { dithiolene })_{2}\right]^{-}$complexes while keeping oxygen atoms for secondary coordination, we envisioned crown ether derivatives as they would provide a powerful coordination function, particularly toward oxophilic cationic centers. Their structure is shown in Scheme 1 with the corresponding abbreviations used in the following.

Dithiolene complexes bearing such a crown ether functionality were first described in 1990 by Green, ${ }^{18}$ aiming at coupling the rich redox chemistry of dithiolene complexes with the cation binding ability of the crown ether group, as demonstrated in the heteroleptic $\mathrm{Cp}_{2} \mathrm{M}\left(\mathrm{S}_{2} \mathrm{O}_{3}\right), \mathrm{M}=\mathrm{Mo}$, $\mathrm{W}$ complexes, and the square planar diamagnetic $\left[\mathrm{Cu}\left(\mathrm{S}_{2} \mathrm{O}_{3}\right)_{2}\right]^{-}$species. This attractive approach was also extended to the corresponding tetrathiafulvalene derivatives, ${ }^{19,20}$ showing also notable electrochemical anodic shifts of the oxidation potentials upon alkaline cation coordination. ${ }^{21}$ However, the coordination ability of these crown ether derivatives has been strictly restricted up to now to alkaline cations: other, eventually paramagnetic, metal cations were never considered. This is all the more unfortunate that these dithiolene complexes can be isolated into various paramagnetic states, with a spin density largely delocalized on the dithiolate ligands while the ether functionalities of the crown ether substituents would be particularly adapted to the coordination of oxophilic metal centres.

We describe here our first results along this line with the synthesis of the crown-ether substituted paramagnetic complex abbreviated as $\left[\mathrm{Ni}\left(\mathrm{S}_{2} \mathrm{O}_{4}\right)_{2}\right]^{1-}$, isolated as its $\mathrm{Na}^{+}$salt and structurally characterized. In the absence of alkaline cations during the synthesis, a mixed salt associating $\left[\mathrm{Ni}\left(\mathrm{S}_{2} \mathrm{O}_{4}\right)_{2}\right]^{-}$units with $\mathrm{Ni}^{2+}$ was isolated, showing an unprecedented solid state association with short $\mathrm{S} \cdots \mathrm{S}$ intermolecular contacts, leading to a pairing of the radical $\left[\mathrm{Ni}\left(\mathrm{S}_{2} \mathrm{O}_{4}\right)_{2}\right]^{-}$into antiferromagnetic uniform spin chains.

\section{Results and discussion}

The preparation of the nickel complex (Scheme 2) relies on the base opening of the dithiocarbonate $\left(\mathrm{S}_{2} \mathrm{O}_{4}\right) \mathrm{C}=\mathrm{O}$, obtained itself from the oxymercuration of known trithiocarbonate ${ }^{19 b}$ $\left(\mathrm{S}_{2} \mathrm{O}_{4}\right) \mathrm{C}=\mathrm{S}$ in $60 \%$ yield. The dithiocarbonate was characterized by single crystal X-ray diffraction (Fig. 1).

When $\mathrm{NaOMe}$ is used as a base to produce the free dithiolate from the dithiocarbonate $\left(\mathrm{S}_{2} \mathrm{O}_{4}\right)=\mathrm{O}$, followed by addition of half an equivalent $\mathrm{NiCl}_{2} \cdot 6 \mathrm{H}_{2} \mathrm{O}$, the initially formed $\left[\mathrm{Ni}\left(\mathrm{S}_{2} \mathrm{O}_{4}\right)_{2}\right]^{2-}$ oxidizes in air to afford the monoanionic complex, isolated as its sodium salt, that is, $\mathrm{Na}\left[\mathrm{Ni}\left(\mathrm{S}_{2} \mathrm{O}_{4}\right)_{2}\right]$. On the other hand, using $(n-\mathrm{Bu})_{4} \mathrm{NOH}$ as a base instead of $\mathrm{NaOMe}$ afforded the $\mathrm{Ni}^{2+}$ salt, formulated as $\left[\mathrm{Ni}, \mathrm{H}_{2} \mathrm{O}\right]_{0.5}\left[\mathrm{Ni}\left(\mathrm{S}_{2} \mathrm{O}_{4}\right)_{2}\right]$. The oxidized neutral complex $\left[\mathrm{Ni}\left(\mathrm{S}_{2} \mathrm{O}_{4}\right)_{2}\right]^{0}$ was obtained from iodine oxidation of the latter monoanionic species.
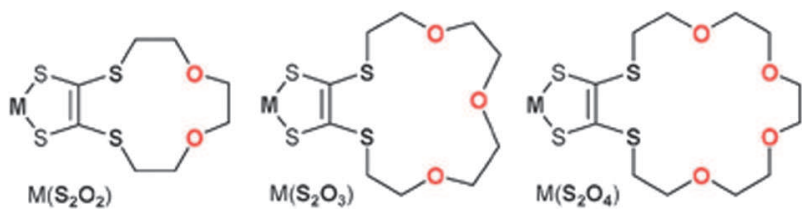

Scheme 1 Crown-ether dithiolene complexes and their acronyms.

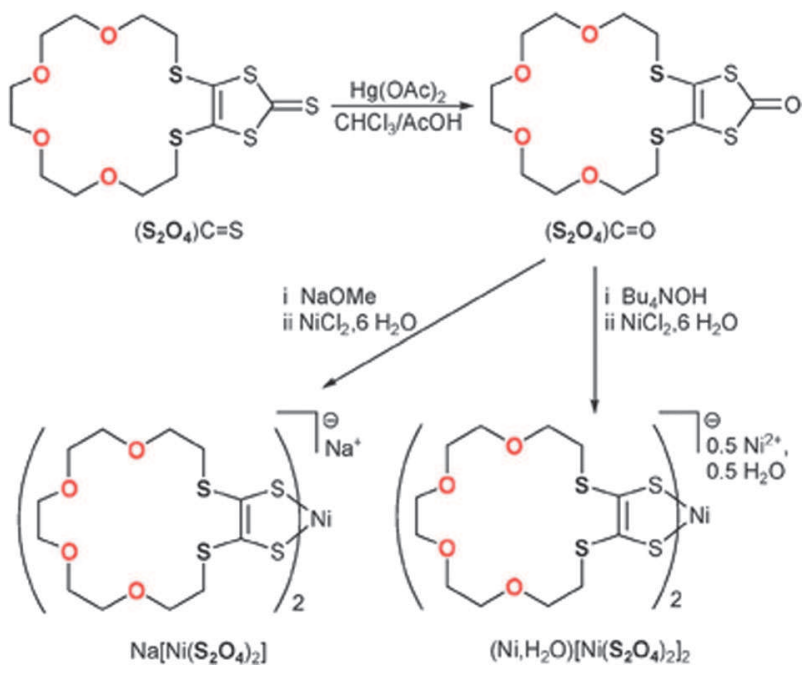

Scheme 2 Synthesis of nickel complexes.

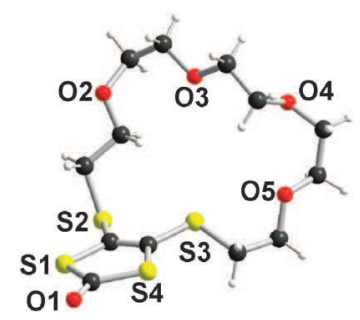

Fig. 1 X-Ray crystal structure of the dithiocarbonate $\left(\mathrm{S}_{2} \mathrm{O}_{4}\right) \mathrm{C}=\mathrm{O}$.

Cyclic voltammetry experiments performed on $\mathrm{Na}\left[\mathrm{Ni}\left(\mathrm{S}_{2} \mathrm{O}_{4}\right)_{2}\right]$ (Fig. 2) show two reversible redox waves associated with the $\left[\mathrm{Ni}\left(\mathrm{S}_{2} \mathrm{O}_{4}\right)_{2}\right]^{-2 /-1}$ and $\left[\mathrm{Ni}\left(\mathrm{S}_{2} \mathrm{O}_{4}\right)_{2}\right]^{-1 / 0}$ redox processes, at $E_{\frac{1}{2}}=-0.64$ and $+0.13 \mathrm{~V}(v s$. SCE) respectively. A third redox process observed at $E_{\mathrm{ox}}=+0.78 \mathrm{~V}$ and associated to the oxidation of the neutral complex is irreversible. Note that the rather low oxidation potential of the monoanionic $\left[\mathrm{Ni}\left(\mathrm{S}_{2} \mathrm{O}_{4}\right)_{2}\right]^{1-}(+0.13 \mathrm{~V})$ gives an explanation for its experimentally observed easy oxidation to the neutral complex.

$\mathrm{Na}\left[\mathrm{Ni}\left(\mathrm{S}_{2} \mathrm{O}_{4}\right)_{2}\right]$ crystallizes in the monoclinic system, space group $\mathrm{C} 2 / c$ with the $\mathrm{Ni}$ atom on an inversion centre while the $\mathrm{Na}$ ion lies on a two-fold axis. As shown in Fig. 3, the $\mathrm{Na}^{+}$cation is coordinated by six oxygen atoms from two

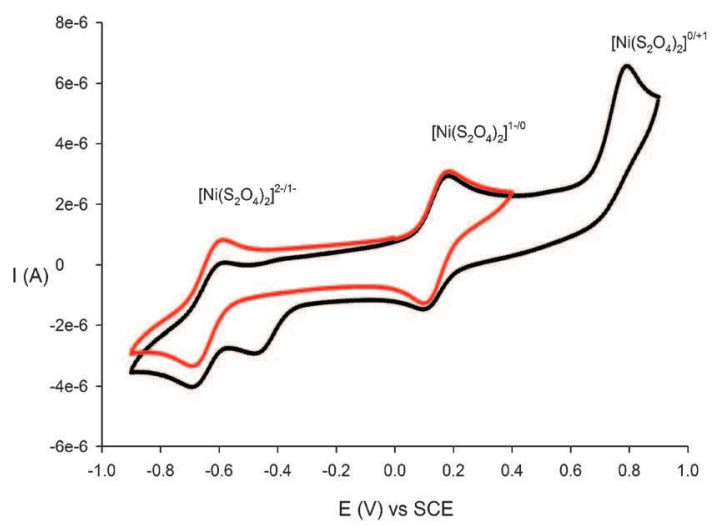

Fig. 2 Cyclic voltamogramm of $\mathrm{Na}\left[\mathrm{Ni}\left(\mathrm{S}_{2} \mathrm{O}_{4}\right)_{2}\right]$, in DMF with $0.2 \mathrm{M}$ $\left(n-\mathrm{Bu}_{4} \mathrm{~N}\right) \mathrm{PF}_{6}$, at $100 \mathrm{mV} \mathrm{s}^{-1}$ scan rate. 


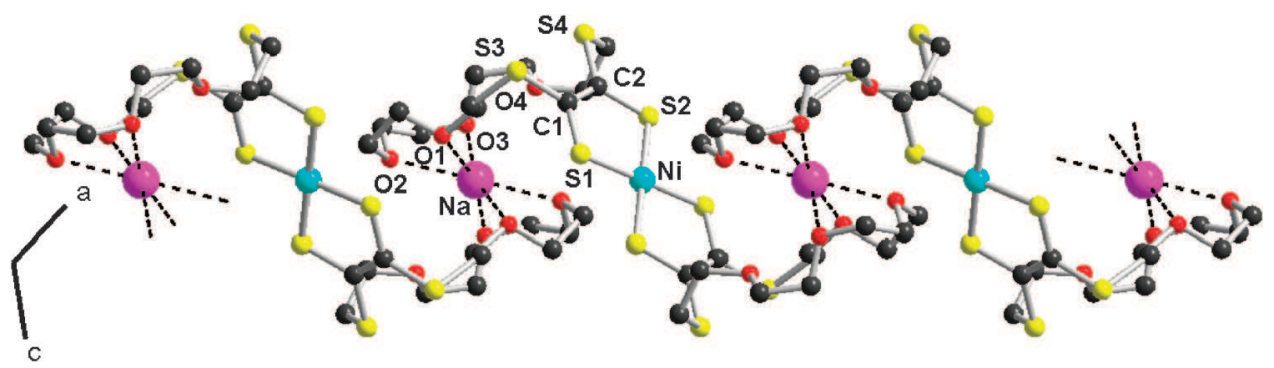

Fig. 3 View of the $\mathrm{Na}\left[\mathrm{Ni}\left(\mathrm{S}_{2} \mathrm{O}_{4}\right)_{2}\right]$ complex, showing the $\mathrm{Na}^{+}$coordination pattern.

neighbouring dithiolene complexes, with $\mathrm{Na}$. . O distances of 2.463(4), 2.523(6) and 2.4651(4) $\AA$ with $\mathrm{O} 1, \mathrm{O} 2$ and $\mathrm{O} 3$ respectively, giving rise to coordination chains running along $a+c$, and demonstrating that the crown ether functions can effectively act as secondary ligands in these dithiolene complexes. The Na..O distances are particularly short when compared with those observed for example in [(18-crown-6) $\left.\mathrm{Na}^{+}\right]$ derivatives where they are usually found around $2.50-2.90 \AA$. An interesting comparison can also be made with the only structurally reported analog incorporating two sulfur atoms, shown in Fig. 4, where the eight-coordinated $\mathrm{Na}^{+}$cation is sandwiched between two dithiatetraoxa crown molecules. ${ }^{22}$ In this salt, the $\mathrm{Na} \cdots \mathrm{O}$ distances are even longer, between 2.85 and $3.11 \AA$.

Intramolecular bond distances within the metallacycle in $\left[\mathrm{Ni}\left(\mathrm{S}_{2} \mathrm{O}_{4}\right)_{2}\right]^{1-}$ (Table 1) are characteristic of radical anion nickel dithiolene complexes such as the analogous thioalkyl substituted $\left[\mathrm{Ni}(\mathrm{dddt})_{2}\right]^{-},{ }^{25}\left[\mathrm{Ni}(\mathrm{pddt})_{2}\right]^{-},{ }^{23}$ or $\left[\mathrm{Ni}\left(\mathrm{F}_{2} \mathrm{pddt}\right)_{2}\right]^{-}$ complexes. $^{24,27}$

Because of its limited solubility, EPR spectra of the sodium salt in solution could be obtained only from DMF solutions with added $\mathrm{CH}_{2} \mathrm{Cl}_{2}$. At room temperature, a single Lorentzian line is observed with $g=2.055$ and a $9.1 \mathrm{G}$ linewidth. In frozen solution (Fig. 5), a rhombic pattern is found with $g_{\max }=2.102, g_{\text {int }}=2.040$ and $g_{\min }=2.001$, comparable to those described for $\left[\mathrm{Ni}(\mathrm{mnt})_{2}\right]^{-}(2.14,2.04,1.99),\left[\mathrm{Ni}(\mathrm{dmit})_{2}\right]^{-}$ $(2.105,2.041,2.001)^{28}$ or $\left[\mathrm{Ni}(\mathrm{dddt})_{2}\right]^{-}[2.119(1), 2.057(1)$, $2.022(1)] .{ }^{29}$ The powder spectrum of $\mathrm{Na}\left[\mathrm{Ni}\left(\mathrm{S}_{2} \mathrm{O}_{4}\right)_{2}\right]$ shows an axial symmetry with $g_{\perp}=2.071$ and $g_{/ /}=2.044$. In the solid state, the radical complexes are fully isolated from each other and the shortest intermolecular S. . S distances exceed $4.88 \AA$. This is also confirmed by the temperature dependence of the magnetic susceptibility, which follows a Curie law in the whole temperature range.

As mentioned above, the $\left[\mathrm{Ni}\left(\mathrm{S}_{2} \mathrm{O}_{4}\right)_{2}\right]^{-1}$ radical anion is oxidation sensitive and many attempts to replace the $\mathrm{Na}^{+}$ cation with other metallic cations very often afforded the neutral oxidized complex $\left[\mathrm{Ni}\left(\mathrm{S}_{2} \mathrm{O}_{4}\right)_{2}\right]^{0}$. The latter was found to crystallize in the triclinic system, space group $P \overline{1}$ with the
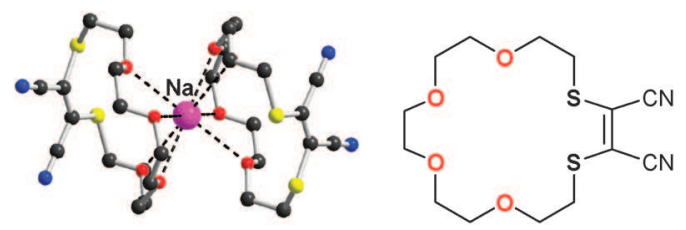

Fig. 4 The structurally characterized $\mathrm{Na}^{+}$salt of a dithia-tetraoxa crown. ${ }^{22}$
Table 1 Intramolecular bond distances within the $\left[\mathrm{Ni}\left(\mathrm{S}_{2} \mathrm{O}_{4}\right)_{2}\right]^{-n}$ and analogous reference compounds known in both oxidation states such as $\left[\mathrm{Ni}(\mathrm{dddt})_{2}\right]^{-n},\left[\mathrm{Ni}(\mathrm{pddt})_{2}\right]^{-n}$ and $\left[\mathrm{Ni}\left(\mathrm{F}_{2} \mathrm{pddt}\right)_{2}\right]^{-n}(n=1,0)$

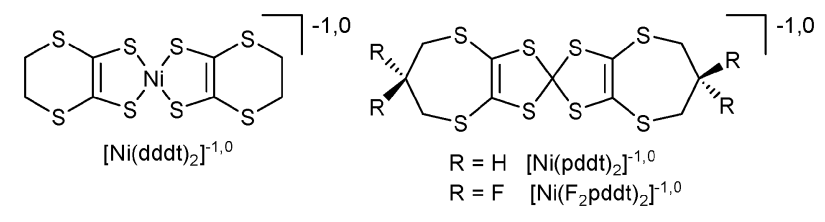

\begin{tabular}{llllll}
\hline & Charge & $\mathrm{Ni}-\mathrm{S}$ & $\mathrm{S}-\mathrm{C}$ & $\mathrm{C}=\mathrm{C}$ & Ref. \\
\hline $\mathrm{Na}\left[\mathrm{Ni}\left(\mathrm{S}_{2} \mathrm{O}_{4}\right)_{2}\right]$ & -1 & $2.142(4)$ & $1.726(6)$ & $1.370(6)$ & This \\
& & $2.155(2)$ & $1.728(5)$ & & work \\
$\left(\mathrm{Ni}, \mathrm{H}_{2} \mathrm{O}\right)_{0.5}\left[\mathrm{Ni}\left(\mathrm{S}_{2} \mathrm{O}_{4}\right)_{2}\right]$ & -1 & $2.140(1)$ & $1.729(4)$ & $1.367(5)$ & This \\
& & & & & work \\
$\mathrm{Et}{ }_{4} \mathrm{~N}\left[\mathrm{Ni}(\mathrm{dddt})_{2}\right]$ & -1 & $2.147(2)$ & $1.735(8)$ & $1.339(11)$ & 29 \\
$\mathrm{Et}_{4} \mathrm{~N}\left[\mathrm{Ni}(\mathrm{pddt})_{2}\right]$ & -1 & $2.142(10)$ & $1.725(20)$ & $1.356(3)$ & 23 \\
$\mathrm{Bu} \mathrm{N}_{4}\left[\mathrm{Ni}\left(\mathrm{F}_{2} \text { pddt }\right)_{2}\right]$ & -1 & $2.150(1)$ & $1.735(4)$ & $1.346(5)$ & 24 \\
{$\left[\mathrm{Ni}\left(\mathrm{S}_{2} \mathrm{O}_{4}\right)_{2}\right]^{0}$} & 0 & $2.134(1)$ & $1.708(2)$ & $1.399(3)$ & This \\
& & $2.136(1)$ & $1.712(2)$ & & work \\
{$\left[\mathrm{Ni}(\mathrm{dddt})_{2}\right]^{0}$} & 0 & $2.121(5)$ & $1.69(2)$ & $1.37(2)$ & 25 \\
{$\left[\mathrm{Ni}(\mathrm{pddt})_{2}\right]^{0}$} & 0 & $2.133(1)$ & $1.712(3)$ & $1.401(4)$ & 26 \\
{$\left[\mathrm{Ni}\left(\mathrm{F}_{2} \mathrm{pddt}\right)_{2}\right]^{0}$} & 0 & $2.133(1)$ & $1.698(3)$ & $1.376(4)$ & 27 \\
\hline
\end{tabular}

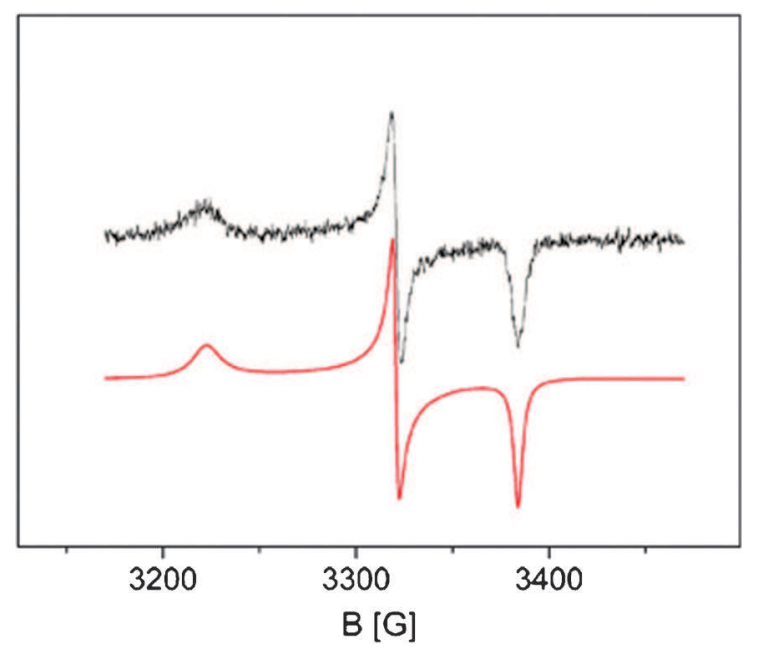

Fig. 5 Frozen solution EPR spectrum of $\mathrm{Na}\left[\mathrm{Ni}\left(\mathrm{S}_{2} \mathrm{O}_{4}\right)_{2}\right]$ (in $\mathrm{DMF} /$ $\mathrm{CH}_{2} \mathrm{Cl}_{2}$ ) with fit in red line (see text).

nickel atom on the inversion centre (Fig. 6). Intramolecular bond distance within the $\mathrm{NiS}_{2} \mathrm{C}_{2}$ metallacycle (Table 1) confirms the oxidation state of the complex, with a notable shortening of the $\mathrm{C}-\mathrm{S}$ and lengthening of the $\mathrm{C}=\mathrm{C}$ bonds when compared with the $\left[\mathrm{Ni}\left(\mathrm{S}_{2} \mathrm{O}_{4}\right)_{2}\right]^{-1}$ radical anion, associated with the partial oxidation of the two dithiolate ligands. 


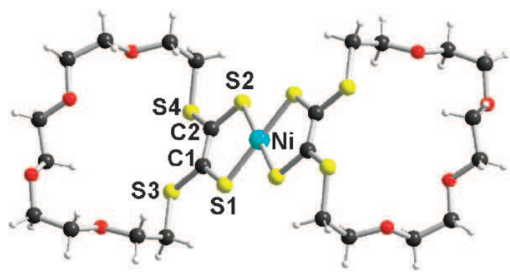

Fig. 6 View of the neutral oxidized complex $\left[\mathrm{Ni}\left(\mathrm{S}_{2} \mathrm{O}_{4}\right)_{2}\right]^{0}$.

When the dithiolene complex is prepared in the absence of $\mathrm{Na}^{+}$cations, using $\mathrm{Bu}_{4} \mathrm{NOH}$ rather than $\mathrm{NaOMe}$, the $\left[\mathrm{Ni}\left(\mathrm{S}_{2} \mathrm{O}_{4}\right)_{2}\right]^{-1}$ radical complex was isolated as $\mathrm{Ni}^{2+}$ salt, together with a water molecule. The salt, formulated as $\left(\mathrm{Ni}, \mathrm{H}_{2} \mathrm{O}\right)_{0.5}\left[\mathrm{Ni}\left(\mathrm{S}_{2} \mathrm{O}_{4}\right)_{2}\right]$, crystallizes in the monoclinic system, space group $C 2 / c$. The dithiolene complex is located on an inversion centre while the $\mathrm{Ni}^{2+}$ cation and water molecule are disordered on the same position, on the two-fold axis (Fig. 7). Intramolecular bond distances within the $\mathrm{NiS}_{2} \mathrm{C}_{2}$ metallacycle (Table 1) are identical to those observed for the sodium salt, confirming the actual formulation. The very peculiar solid state organization parallels that which was observed with the $\mathrm{Na}^{+}$salt, where the sodium site would be alternatively occupied by $\mathrm{a} \mathrm{Ni}^{2+}$ or a water molecule, allowing for lattice electro-neutrality. At variance however with the structure of $\mathrm{Na}\left[\mathrm{Ni}\left(\mathrm{S}_{2} \mathrm{O}_{4}\right)_{2}\right]$, the coordination of the $\mathrm{Ni}^{2+} / \mathrm{H}_{2} \mathrm{O}$ centers by the crown ether oxygen atoms is much weaker, with $\mathrm{Ni}$...O distances of 2.977(3), 2.885(4) and 2.898(3) ^ with O1, O2 and $\mathrm{O} 3$ respectively. These distances are larger than those observed above in $\mathrm{Na}\left[\mathrm{Ni}\left(\mathrm{S}_{2} \mathrm{O}_{4}\right)_{2}\right]$ with the $\mathrm{Na}^{+}$cation and also than those reported in the $\mathrm{Ni}^{2+}$ crown ether complexes such as $\left[\mathrm{Ni}(18 \text {-crown-6)(EtOH })_{3}\right]\left(\mathrm{PF}_{6}\right)_{2}$ where three out of the six available $\mathrm{O}$ atoms coordinate $\mathrm{Ni}^{2+}$ with $\mathrm{Ni} \cdot \mathrm{OO}$ distance around 2.03-2.11 $\AA$, ${ }^{30}$ or $\left[\mathrm{Ni}\left(15\right.\right.$-crown-5) $\left.\left(\mathrm{H}_{2} \mathrm{O}\right)_{2}\right]\left(\mathrm{NO}_{3}\right)_{2}$ and $\left[\mathrm{Ni}\left(15\right.\right.$-crown-5) $\left.\left(\mathrm{H}_{2} \mathrm{O}\right)_{2}\right]\left(\mathrm{HSO}_{4}\right)_{2}$ with $\mathrm{Ni}^{2+} \ldots \mathrm{O}$ distances 2.06-2.30 $\AA^{31}$ This tends to indicate that the $\mathrm{Ni}^{2+}$ coordination is not the only driving force directing the supramolecular arrangement of the structure.

From a magnetic point of view, $\left(\mathrm{Ni}, \mathrm{H}_{2} \mathrm{O}\right)\left[\mathrm{Ni}\left(\mathrm{S}_{2} \mathrm{O}_{4}\right)_{2}\right]_{2}$ can be described as chains of alternative $\mathrm{Ni}^{2+}$ cations in an octahedral environment with an anticipated $S=1$ spin state, and $\left[\mathrm{Ni}\left(\mathrm{S}_{2} \mathrm{O}_{4}\right)_{2}\right]^{-}$radical anion complexes with $S=\frac{1}{2}$, also taking into consideration that the $\mathrm{Ni}^{2+}$ occupancy is only $50 \%$. Temperature dependence of the magnetic susceptibility for a trimolecular $\left(\mathrm{Ni}^{2+}\right)\left[\mathrm{Ni}\left(\mathrm{S}_{2} \mathrm{O}_{4}\right)_{2}\right]_{2}$ formulation, reported here as the $\chi \times T$ product, is given in Fig. 8 . We note that the room

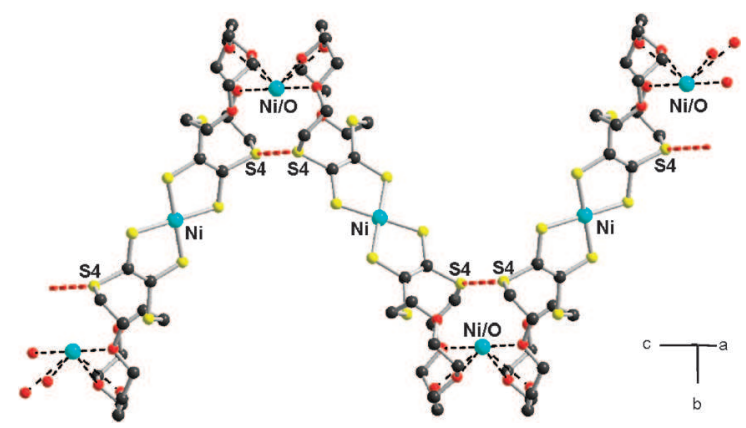

Fig. 7 Solid state organization within $\left(\mathrm{Ni}, \mathrm{H}_{2} \mathrm{O}\right)_{0.5}\left[\mathrm{Ni}\left(\mathrm{S}_{2} \mathrm{O}_{4}\right)_{2}\right]$. Hydrogen atoms were omitted for clarity.

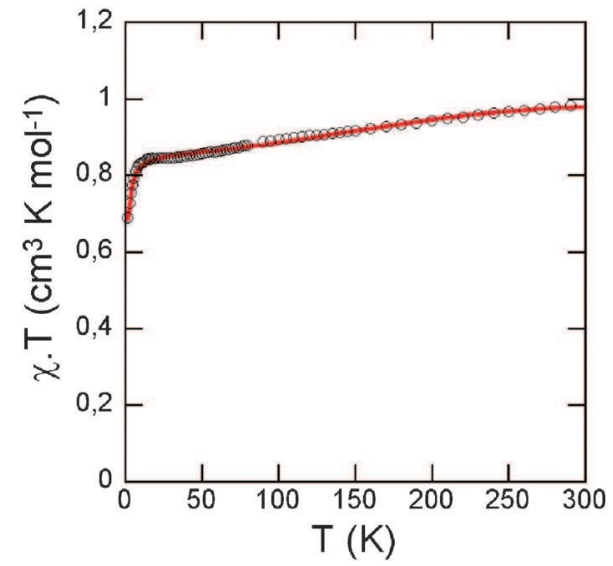

Fig. 8 Temperature dependence of the $\chi \times T$ product for $\left(\mathrm{Ni}^{2+}, \mathrm{H}_{2} \mathrm{O}\right)\left[\mathrm{Ni}\left(\mathrm{S}_{2} \mathrm{O}_{4}\right)_{2}{ }^{-1}\right]_{2}$. The solid line is the fit for the sum of the $S=1 \mathrm{Ni}^{2+}$ species and uniform spin chain of antiferromagnetically coupled dithiolene complexes (see text).

temperature value of $\chi \times T$ does not exceed $1.0 \mathrm{~cm}^{3} \mathrm{~K} \mathrm{~mol}^{-1}$, while a total value of $1.75=1$ (for the $\mathrm{Ni}^{2+}$ ) $+2 \times 0.375$ (for the dithiolene complexes) would have been expected, considering a $g=2$ value for both magnetic species, in the absence of any antiferromagnetic interactions.

Closer inspection of the crystal structure gives a rationale for this unexpected behaviour. As shown in Fig. 7, we note the presence of an extremely short intermolecular S ...S contact between the radical dithiolene complexes with $\mathrm{S} 4 \cdots \mathrm{S} 4^{i}$ at 3.332(2) $\AA(i: 2-x, y, 1.5-z)$. This intermolecular distance should be compared to the sulfur...sulfur van der Waals contact distance at $3.70 \AA$. Furthermore, while the spin density in most radical nickel bis(dithiolene) complexes is essentially delocalized on the $\mathrm{Ni}\left(\mathrm{S}_{2} \mathrm{C}_{2}\right)_{2}$ core, complexes with thioether (-SR) substituents are well known to allow a sizeable fraction of the spin density to delocalize on the outer sulfur atoms such as atom $\mathrm{S} 4$ in $\left[\mathrm{Ni}\left(\mathrm{S}_{2} \mathrm{O}_{4}\right)_{2}\right]^{-1}$. $^{2 a}$ The overlap associated with the $\mathrm{S} 4 \cdots \mathrm{S} 4^{\mathrm{i}}$ intermolecular interaction is therefore at the origin of a strong antiferromagnetic interaction between the radical dithiolene complexes, which would then form a uniform chain of spins running along the $c$ axis, independently from the $\mathrm{Ni}^{2+}$ cations. Accordingly, a tentative fit of the $\chi \times T$ product was performed (see Fig. 8), with the susceptibility $\chi$ as a sum of the CurieWeiss contribution of the $S=1 \mathrm{Ni}^{2+}$ species, $\chi_{\mathrm{CW}}=1 /(T-\theta)$, with the contribution of a uniform spin chain for the dithiolene complexes noted $\chi_{\mathrm{BF}}$, associated with the following Hamiltonian $H=-J \sum_{i=1}^{n-1} S_{i} S_{i+1} \cdot{ }^{32,33}$ It gives $\chi=\chi_{0}+x\left(\chi_{\mathrm{CW}}+2 \chi_{\mathrm{BF}}\right)$ with $\chi_{0}=-0.8 \times 10^{-4} \mathrm{~cm}^{3} \mathrm{~K} \mathrm{~mol}^{-1}, x=0.86, \theta=-0.51(1) \mathrm{K}$ and $J / k=-340(10) \mathrm{K}\left(J=-236 \mathrm{~cm}^{-1}\right)$.

In conclusion, we have shown here that dithiolene complexes substituted with crown ether moieties, investigated up to now only with alkaline cations in solution, can be used as metalloligands toward $3 \mathrm{~d}$ magnetic metal cations for the elaboration of more complex magnetic systems. The obtained salt of $\left[\mathrm{Ni}\left(\mathrm{S}_{2} \mathrm{O}_{4}\right)_{2}\right]^{-\bullet}$ and $\mathrm{Ni}^{2+}$ illustrates however that this attractive approach is always in competition with direct antiferromagnetic interactions between the dithiolene complexes. This work is currently being extended to trivalent metal cations such as rare-earth cations as well as to smaller crown-ether moieties. 


\section{Experimental}

All manipulations were performed under argon by use of Schlenk techniques. Solvents $\left(\mathrm{MeOH}, \mathrm{DMF}\right.$ and $\left.\mathrm{Et}_{2} \mathrm{O}\right)$ were distilled prior to use and degassed with argon.

\section{Synthesis of the dithiocarbonate $\left(\mathrm{S}_{2} \mathrm{O}_{4}\right) \mathrm{C}=\mathrm{O}$}

A $100 \mathrm{~mL}$ round bottom flask containing acetic acid $(20 \mathrm{~mL})$ and chloroform $(7 \mathrm{~mL})$ was charged with $\left(\mathrm{S}_{2} \mathrm{O}_{4}\right) \mathrm{C}=\mathrm{S}^{19 b}$ $(0.470 \mathrm{~g}, 1.17 \mathrm{mmol})$ and $\mathrm{Hg}(\mathrm{OAc})_{2}(0.820 \mathrm{~g}, 2.57 \mathrm{mmol})$. The reaction mixture was refluxed for $2 \mathrm{~h}$. After cooling to room temperature, the reaction mixture was filtered through Celite $^{\mathbb{R}}$ and the filtrate evaporated on the rotary evaporator. The residue was taken up in chloroform, filtered and the filtrate was concentrated, leaving an orange oil, purified by column chromatography (Silica, eluent: $\mathrm{CH}_{2} \mathrm{Cl}_{2}$ /acetone $5: 1 \mathrm{vv}$, $R_{\mathrm{f}}=0.88$ ). After concentrating the second yellow band eluted from the column, the product crystallized in the form of yellow needles $(0.276 \mathrm{~g}, 61 \%)$. Mp 71-72 ${ }^{\circ} \mathrm{C} .{ }^{1} \mathrm{H}$ NMR $(300 \mathrm{MHz}$, $\left.\mathrm{CDCl}_{3}, \mathrm{TMS}\right) \delta 3.00(\mathrm{t}, J=6 \mathrm{~Hz}, 4 \mathrm{H}), 3.61(\mathrm{~s}, 12 \mathrm{H}), 3.71$ $(\mathrm{t}, J=6 \mathrm{~Hz}, 4 \mathrm{H}) .{ }^{13} \mathrm{C} \mathrm{NMR}\left(300 \mathrm{MHz}, \mathrm{CDCl}_{3}, \mathrm{TMS}\right) \delta 36.20$, 69.59, 70.59, 70.78, 70.81, 127.43, 189.85. Elem. Anal. Calcd for $\mathrm{C}_{13} \mathrm{H}_{20} \mathrm{~S}_{4} \mathrm{O}_{5}$. C, 40.60; H, 5.24\%. Found: C, 40.39; H, 5.22\%.

\section{Synthesis of $\mathrm{Na}\left[\mathrm{Ni}\left(\mathrm{S}_{2} \mathrm{O}_{4}\right)_{2}\right]$}

A Schlenk tube was charged with $\mathrm{MeOH}(5 \mathrm{~mL})$ and sodium $(0.010 \mathrm{~g})$ for the in situ preparation on $\mathrm{NaOMe}$. After the complete dissolution of $\mathrm{Na},\left(\mathrm{S}_{2} \mathrm{O}_{4}\right)=\mathrm{O}(0.085 \mathrm{~g}, 0.22 \mathrm{mmol})$ was added and the solution stirred for $1 \mathrm{~h}$. Addition of $\mathrm{NiCl}_{2} \cdot 6 \mathrm{H}_{2} \mathrm{O}(0.026 \mathrm{~g}, 0.11 \mathrm{mmol})$ to the yellow solution yields a brown precipitate. The reaction was left for stirring for another hour. It was then filtered and the brown solid was dissolved in $\mathrm{DMF}$, filtered and set to crystallize by $\mathrm{Et}_{2} \mathrm{O}$ vapor diffusion. $\mathrm{X}$-Ray diffraction quality single crystals were obtained after one week $(0.07 \mathrm{~g}, 70 \%)$. Elem. Anal. Cald. for $\mathrm{C}_{24} \mathrm{H}_{40} \mathrm{NaNiO}_{8} \mathrm{~S}_{8}: \mathrm{C}$, 36.27; H, 5.07\%. Found: C, 36.30; H, 5.07\%. UV-vis-NIR (DMF): $\lambda_{\text {max }}=1010 \mathrm{~nm}\left(\varepsilon=8437 \mathrm{~L} \mathrm{~mol}^{-1} \mathrm{~cm}^{-1}\right)$.

\section{Synthesis of $\left(\mathrm{Ni}, \mathrm{H}_{2} \mathrm{O}\right)\left[\mathrm{Ni}\left(\mathrm{S}_{2} \mathrm{O}_{4}\right)_{2} \mathbf{l}_{2}\right.$}

A Schlenk tube was charged with $\mathrm{MeOH}(15 \mathrm{~mL}),\left(\mathrm{S}_{2} \mathrm{O}_{4}\right)=\mathrm{O}$ $(0.1 \mathrm{~g}, 0.25 \mathrm{mmol})$ and $\mathrm{Bu}_{4} \mathrm{NOH} 1 \mathrm{M}$ in $\mathrm{MeOH}(0.55 \mathrm{~mL}$, $0.55 \mathrm{mmol})$. After the complete dissolution of $\left(\mathrm{S}_{2} \mathrm{O}_{4}\right)=\mathrm{O}$ the solution was stirred for $1 \mathrm{~h}$. Addition of $\mathrm{NiCl}_{2} \cdot 6 \mathrm{H}_{2} \mathrm{O}(0.060 \mathrm{~g}$, $0.26 \mathrm{mmol}$ ) to the yellow solution yields a brown precipitate. The reaction was left for stirring for another hour. It was then filtered and the brown solid was dissolved in DMF, filtered and set to crystallize by $\mathrm{Et}_{2} \mathrm{O}$ vapor diffusion. X-Ray diffraction quality single crystals were obtained after one week $(0.056 \mathrm{~g}$, $56 \%$ ). Elem. Anal. Calcd for $\mathrm{C}_{48} \mathrm{H}_{82} \mathrm{Ni}_{3} \mathrm{O}_{17} \mathrm{~S}_{16}$ : C, 35.58; H, 5.10\%. Found: C, 35.29; H, 4.98\%. UV-vis-NIR (DMF): $\lambda_{\max }=1011 \mathrm{~nm}\left(\varepsilon=9900 \mathrm{~L} \mathrm{~mol}^{-1} \mathrm{~cm}^{-1}\right)$.

\section{Synthesis of $\left[\mathrm{Ni}\left(\mathrm{S}_{2} \mathrm{O}_{4}\right)_{2}\right]_{2}$}

A Schlenk tube was charged with DMSO (3 mL) and $\left(\mathrm{Ni}, \mathrm{H}_{2} \mathrm{O}\right)\left[\mathrm{Ni}\left(\mathrm{S}_{2} \mathrm{O}_{4}\right)_{2}\right]_{2}(40.0 \mathrm{mg}, 0.05 \mathrm{mmol}) . \mathrm{I}_{2}(20.2 \mathrm{mg}$, $0.08 \mathrm{mmol})$ in DMSO $(1.0 \mathrm{~mL})$ is added to the solution. A precipitate appears and the suspension was stirred for 15 minutes. EtOH was then added to complete the precipitation and the solid, once filtered and dried by suction, was redissolved in $\mathrm{CH}_{2} \mathrm{Cl}_{2}$, which, upon diffusion of $\mathrm{Et}_{2} \mathrm{O}$ vapours, afforded needle shaped crystals $\left(27 \mathrm{mg} \mathrm{70 \%}\right.$ ). Elem. Anal. Calcd. for $\mathrm{C}_{24} \mathrm{H}_{40} \mathrm{NiO}_{8} \mathrm{~S}_{8}$ :

Table 2 Crystallographic data

\begin{tabular}{|c|c|c|c|c|}
\hline Compound & $\left(\mathrm{S}_{2} \mathrm{O}_{4}\right) \mathrm{C}=\mathrm{O}$ & $\mathrm{Na}\left[\mathrm{Ni}\left(\mathrm{S}_{2} \mathrm{O}_{4}\right)_{2}\right]$ & {$\left[\mathrm{Ni}\left(\mathrm{S}_{2} \mathrm{O}_{4}\right)_{2}\right]^{0}$} & $\left(\mathrm{Ni}, \mathrm{H}_{2} \mathrm{O}\right)\left[\mathrm{Ni}\left(\mathrm{S}_{2} \mathrm{O}_{4}\right)_{2}\right]_{2}$ \\
\hline Formula & $\mathrm{C}_{13} \mathrm{H}_{20} \mathrm{O}_{5} \mathrm{~S}_{4}$ & $\mathrm{C}_{24} \mathrm{H}_{40} \mathrm{NaNiO}_{8} \mathrm{~S}_{8}$ & $\mathrm{C}_{24} \mathrm{H}_{40} \mathrm{NiO}_{8} \mathrm{~S}_{8}$ & $\mathrm{C}_{24} \mathrm{H}_{40} \mathrm{Ni}_{1.5} \mathrm{O}_{8.5} \mathrm{~S}_{8}$ \\
\hline $\mathrm{FW} / \mathrm{g} \mathrm{mol}^{-1}$ & 384.53 & 794.74 & 771.75 & 809.14 \\
\hline Crystal color & Colorless & Black & Black & Black \\
\hline Crystal size $/ \mathrm{mm}$ & $0.25 \times 0.11 \times 0.10$ & $0.13 \times 0.07 \times 0.06$ & $0.21 \times 0.12 \times 0.06$ & $0.30 \times 0.10 \times 0.08$ \\
\hline Crystal system & Monoclinic & Monoclinic & Triclinic & Monoclinic \\
\hline Space group & $P 2_{1} / c$ & $C 2 / c$ & $P \overline{1}$ & $C 2 / c$ \\
\hline$T / \mathrm{K}$ & $293(2)$ & $150(2)$ & $150(2)$ & $293(2)$ \\
\hline$a / \AA ̊$ & $8.2045(16)$ & $23.6588(14)$ & $9.1918(4)$ & $13.4074(4)$ \\
\hline$b / \AA$ & $11.888(2)$ & $10.1920(6)$ & $9.5486(4)$ & $14.0031(4)$ \\
\hline$c / \AA$ & $17.949(4)$ & $17.5265(12)$ & $10.6697(4)$ & $19.1875(6)$ \\
\hline$\alpha /^{\circ}$ & 90.0 & 90.0 & $67.4590(10)$ & 90.0 \\
\hline$\beta /^{\circ}$ & $99.79(3)$ & $127.742(2)$ & $74.151(2)$ & $104.5930(10)$ \\
\hline$\gamma / 1^{\circ}$ & 90.0 & 90.0 & $84.463(2)$ & 90.0 \\
\hline$V / \AA^{3}$ & $1725.1(6)$ & $3342.0(4)$ & $832.01(6)$ & $3486.15(18)$ \\
\hline Z & 4 & 4 & 1 & 4 \\
\hline$D_{\text {calc }} / \mathrm{g} \mathrm{cm}^{-3}$ & 1.481 & 1.580 & 1.540 & 1.542 \\
\hline$\mu / \mathrm{mm}^{-1}$ & 0.569 & 1.137 & 1.128 & 1.341 \\
\hline Total refls. & 16204 & 12062 & 10148 & 15378 \\
\hline Abs. corr. & Multi-scan & Multi-scan & Multi-scan & Multi-scan \\
\hline$T_{\min }, T_{\max }$ & $0.928,0945$ & $0.909,0.934$ & $0.850,0.935$ & $0.878,0.917$ \\
\hline Unique refls. & 3937 & 3800 & 3777 & 3991 \\
\hline$R_{\text {int }}$ & 0.0541 & 0.0563 & 0.0317 & 0.0268 \\
\hline Unique refls $(I>2 \sigma(I))$ & 2726 & 2562 & 3498 & 3469 \\
\hline Refined param. & 199 & 192 & 187 & 192 \\
\hline$R_{1}(I>2 \sigma(I))$ & 0.0357 & 0.0417 & 0.0233 & 0.0528 \\
\hline$w R_{2}$ (all data) & 0.0916 & 0.1568 & 0.0809 & 0.1811 \\
\hline Goodness-of-fit & 1.088 & 1.044 & 1.206 & 1.061 \\
\hline Res. dens. $/ \mathrm{e} \AA^{-3}$ & $0.299,-0.284$ & $0.523,-0.617$ & $0.365,-0.384$ & $1.352,-0.849$ \\
\hline
\end{tabular}


C, 37.35; H, 5.22\%. Found C, 37.46; H, 5.76\%. UV/Vis/NIR (DMF) $\lambda=1015 \mathrm{~nm}\left(\varepsilon=10970 \mathrm{~L} \mathrm{~mol}^{-1} \mathrm{~cm}^{-1}\right)$.

\section{X-Ray diffraction studies}

Single crystals were mounted on the top of a thin glass fiber. Data were collected on a Nonius KappaCCD diffractometer at room temperature with graphite-monochromated $\mathrm{Mo}-\mathrm{K} \alpha$ radiation $(\lambda=0.71073 \AA)$. Structures were solved by direct methods (SHELXS-97) and refined (SHELXL-97) by full-matrix least-squares methods, ${ }^{34}$ as implemented in the WinGX software package. ${ }^{35}$ Absorption corrections were applied. Hydrogen atoms were introduced at calculated positions (riding model), included in structure factor calculations, and not refined. Crystallographic data are summarized in Table 2.

\section{Magnetic properties}

The magnetic susceptibility measurements were obtained from a Quantum Design SQUID magnetometer MPMS-XL. This magnetometer works between 1.8 and $400 \mathrm{~K}$ for dc applied fields ranging from -5 to $5 \mathrm{~T}$. Measurements were performed on polycrystalline samples of $\mathrm{Na}\left[\mathrm{Ni}\left(\mathrm{S}_{2} \mathrm{O}_{4}\right)_{2}\right](5.7 \mathrm{mg})$ and $\left(\mathrm{Ni}, \mathrm{H}_{2} \mathrm{O}\right)\left[\mathrm{Ni}\left(\mathrm{S}_{2} \mathrm{O}_{4}\right)_{2}\right](14 \mathrm{mg})$. The magnetic data were corrected for the sample holder and the diamagnetic contributions. EPR spectra were obtained either on a X-band Bruker EMX-8/2.7 spectrometer equipped with a liquid nitrogen cooling system. Simulations were performed with Bruker WinEPR Symphonia.

\section{Acknowledgements}

Financial support for this project was obtained from the University of Padova (Italy), the Polish-French Polonium 2009-2010 program no. 20083YF and the ANR (Paris) under contract no. ANR-09-BLAN-0175-03. We thank CDIFX Rennes for access to X-ray diffraction facilities.

\section{References}

1 For recent reviews on dithiolene complexes see: (a), Prog. Inorg. Chem., 2003, 52, 1-738; (b) , Coord. Chem. Rev., 2010, 254(13-14), 1357-1588.

2 (a) R. Kato, Chem. Rev., 2004, 104, 5319; (b) C. Faulmann and P. Cassoux, Prog. Inorg. Chem., 2003, 52, 399; (c) A. Kobayashi, E. Fujiwara and H. Kobayashi, Chem. Rev., 2004, 104, 5243.

3 (a) N. Robertson and L. Cronin, Coord. Chem. Rev., 2002, 227, 93; (b) P. I. Clemenson, Coord. Chem. Rev., 1990, 106, 171.

4 (a) G. Rindorf, N. Thorup, T. Bjørnholm and K. Bechgaard, Acta Crystallogr., Sect. C: Cryst. Struct. Commun., 1990, C46, 1437; (b) N. C. Schiødt, T. Bjørnholm, K. Bechgaard, J. J. Neumeier, C. Allgeier, C. S. Jacobsen and N. Thorup, Phys. Rev. B: Condens. Matter, 1996, 53, 1773.

5 (a) N. Tenn, N. Bellec, O. Jeannin, L. Piekara-Sady, P. AubanSenzier, J. Iniguez, E. Canadell and D. Lorcy, J. Am. Chem. Soc., 2009, 131, 16961; (b) O. J. Dautel, M. Fourmigué, E. Canadell and P. Auban-Senzier, Adv. Funct. Mater., 2002, 12, 693.

6 (a) D. Coucouvanis, J. Am. Chem. Soc., 1970, 92, 707; (b) D. Coucouvanis, N. C. Baenziger and S. M. Johnson, J. Am. Chem. Soc., 1973, 95, 3875.

7 For recent reviews of other classes of complexes as metallo-ligands, see for example: (a) E. Pardo, R. Ruiz-Garcia, J. Cano, X. Ottenwaelder, R. Lescouezec, Y. Journaux, F. Lloret and M. Julve, Dalton Trans., 2008, 2780; (b) M. C. Dul, E. Pardo, R. Lescouezec, Y. Journaux, J. Ferrando-Soria, R. Ruiz-Garcia, J. Cano, M. Julve, F. Lloret, D. Cangussu, C. L. M. Pereira, H. O. Stumpf, J. Pasan and C. RuizPerez, Coord. Chem. Rev., 2010, 254, 2281.

8 O. Jeannin, J. Delaunay, F. Barrière and M. Fourmigué, Inorg. Chem., 2005, 44, 9763.
9 L. N. Dawe, L. Turnbow, J. M. Miglioi, M. L. Taliaferro, W. W. Shum, J. D. Bagnato, L. N. Zakharov, A. L. Rheingold, A. M. Arif, M. Fourmigué and J. S. Miller, Inorg. Chem., 2005, 44, 7530.

10 O. Jeannin, R. Clérac, T. Cauchy and M. Fourmigué, Inorg. Chem., 2008, 47, 10656.

11 H. Hiraga, H. Miyasaka, K. Nakata, T. Kajiwara, S. Takaishi, Y. Oshima, H. Nojiri and M. Yamashita, Inorg. Chem., 2007, 46, 9661

12 A. M. Madalan, N. Avarvari, M. Fourmigué, R. Clérac, L. Chibotaru, S. Clima and M. Andruh, Inorg. Chem., 2008, 47, 940

13 (a) Y. Kobayashi, B. Jacobs, M. D. Allendorf and J. R. Long, Chem. Mater., 2010, 22, 4120; (b) S. Takaishi, M. Hosoda, T. Kajiwara, H. Miyasaka, M. Yamashita, Y. Nakanishi, Y. Kitagawa, K. Yamaguchi, A. Kobayashi and H. Kitagawa, Inorg. Chem., 2009, 48, 9048.

14 (a) S. Rabaca, D. Belo, A. C. Cerdeira, S. I. G. Dias, M. B. C. Branco, L. C. J. Pereira, I. C. Santos, M. Fourmigué and M. Almeida, CrystEngComm, 2009, 11, 2154; (b) S. Rabaca, A. C. Cerdeira, A. I. S. Neves, S. I. G. Dias, C. Mézière, I. C. Santos, L. C. J. Pereira, M. Fourmigué, R. T. Henriques and M. Almeida, Polyhedron, 2009, 28, 1069.

15 (a) A. Gleizes and M. Verdaguer, J. Am. Chem. Soc., 1981, 103, 7373; (b) A. Gleizes and M. Verdaguer, J. Am. Chem. Soc., 1984, 106, 3727.

16 M. Mitsumi, H. Ökawa, H. Sakiyama, M. Ohba, N. Matsumoto, T. Kurisaki and H. Wakita, J. Chem. Soc., Dalton Trans., 1993, 2991.

17 Y. Ono, M. Okubo and N. Kojima, Solid State Commun., 2003, 126, 291.

18 M. L. H. Green, W. B. Heuer and G. C. Saunders, J. Chem. Soc., Dalton Trans., 1990, 3789.

19 (a) K. Christiansen, J. Becher and T. K. Hansen, Tetrahedron Lett., 1992, 33, 3035; (b) T. K. Hansen, T. Joergensen, P. C. Stein and J. Becher, J. Org. Chem., 1992, 57, 6403; (c) T. K. Hansen, T. Joergensen, F. Jensen, P. H. Thygesen, K. Christiansen, M. B. Hursthouse, M. E. Harman, M. A. Malik and B. Girmay, J. Org. Chem., 1993, 58, 1359.

20 (a) A. J. Moore, L. M. Goldenberg, M. R. Bryce, P. C. Petty, J. Moloney, J. A. K. Howard, M. J. Joyce and S. N. Port, J. Org. Chem., 2000, 65, 8269; (b) M. R. Bryce, A. S. Batsanov, T. Finn, T. K. Hansen, A. J. Moore, J. A. K. Howard, M. Kamenjicki, I. K. Lednev and S. A. Asher, Eur. J. Org. Chem., 2001, 933.

21 (a) T. K. Hansen, T. Joergensen and J. Becher, J. Chem. Soc., Chem. Commun., 1992, 1550; (b) S.-G. Liu, H. Liu, K. Bandyopadhyay, Z. Gao and L. Echegoyen, J. Org. Chem., 2000, 65, 3292; (c) N. Malhotra, P. Roepstorff, T. K. Hansen and J. Becher, J. Am. Chem. Soc., 1990, 12, 3709; (d) Y. Ji, R. Zhang, Y.-J. Li, Y.-Z. Li, J.-L. Zuo and X.-Z. You, Inorg. Chem., 2007, 46, 866; (e) W. Liu, Y. Chen, R. Wang, X.-H. Zhou, J.-L. Zuo and X.-Z. You, Organometallics, 2008, 27, 2990.

22 H.-J. Drexler, I. Starke, M. Grotjahn, H. Reinke, E. Kleinpeter and H.-J. Holdt, Z. Naturforsch., B: Chem. Sci., 1999, 54, 799.

23 R. D. Bereman and H. Lu, Inorg. Chim. Acta, 1993, 204, 53.

24 O. J. Dautel and M. Fourmigué, Inorg. Chem., 2001, 40, 2083.

25 H. Kim, A. Kobayashi, Y. Sasaki, R. Kato and H. Kobayashi, Bull. Chem. Soc. Jpn., 1988, 61, 579.

26 U. Geiser, S. F. Tytko, T. J. Allen, H. H. Wang, A. M. Kini and J. M. Williams, Acta Crystallogr., Sect. C: Cryst. Struct. Commun., 1991, 47, 1164.

27 O. J. Dautel, M. Fourmigué, E. Canadell and P. Auban-Senzier, Adv. Funct. Mater., 2002, 12, 693.

28 R. Kirmse, J. Stach, W. Dietzsch, G. Steimecke and E. Hoyer, Inorg. Chem., 1980, 19, 2679.

29 C. T. Vance, R. D. Bereman, J. Bordner, W. E. Hatfield and J. H. Helms, Inorg. Chem., 1985, 24, 2905.

30 S. B. Larson, S. H. Simonsen, J. N. Ramsden and J. J. Lagowski, Acta Crystallogr., Sect. C: Cryst. Struct. Commun., 1989, 45, 161.

$31 \mathrm{Ni}^{2+} \ldots \mathrm{O}$ bond distances were taken from the low temperature, non-disordered phases: (a) M. A. Siegler, X. Hao, S. Parkin and C. P. Brock, Acta Crystallogr., Sect. B: Struct. Sci., 2008, 64, 738; (b) M. A. Siegler and E. Stavitski, Acta Crystallogr., Sect. B: Struct. Sci., 2010, 66, 430.

32 J. C. Bonner and M. E. Fisher, Phys. Rev. A: At., Mol., Opt. Phys., 1964, 135, 640.

33 (a) W. Estes, D. P. Gavel, W. E. Hatfield and D. Hogdson, Inorg. Chem., 1978, 17, 1415; (b) O. Kahn, Molecular Magnetism, VCH, Weinheim, 1993, ch. 11.

34 G. M. Sheldrick, SHELX97-Programs for Crystal Structure Analysis (Release 97-2), 1998.

35 L. J. Farrugia, J. Appl. Crystallogr., 1999, 32, 837. 